\title{
PENENTUAN VARIABILITAS AWAN MENGGUNAKAN SATELIT HIMAWARI-8 DI BANDARA TUNGGULWULUNG SEBAGAI DAMPAK FENOMENA SIKLON TROPIS CEMPAKA
}

\author{
DESNAENI HASTUTI ${ }^{-1 *}$, PRASETYO UMAR FIRDIANTO ${ }^{-2}$, YANUAR HENRY PRIBADI $^{-3}$ \\ 1-2 Program Studi Meteorologi \\ Sekolah Tinggi Meteorologi Klimatologi Geofisika \\ Jl. Perhubungan I No. 5 Pondok Betung, Pondok Aren, Bintaro-Tangerang Selatan, Banten 15221 \\ 3 Stasiun Klimatologi Pondok Betung \\ Jl. Raya KodamBintaro No.82 Pondok Betung, Pondok Aren, Bintaro- Tangerang Selatan, 15221 \\ *email : desnaeni.hastuti@gmail.com
}

\begin{abstract}
Abstrak. Pada tanggal 27 November 2017 jam 19.00 WIB terjadi fenomena Siklon Tropis Cempaka di Perairan Selatan Jawa. Fenomena tersebut disebabkan oleh anomali dan kenaikan suhu permukaan laut yang cukup signifikan di wilayah tersebut sehingga memicu transfer energi yang besar dalam interaksi laut dan atmosfer. Akibatnya terjadi perubahan cuaca terutama kondisi awan yang dapat mengganggu kegiatan penerbangan di Bandara Tunggulwulung, Cilacap Jawa Tengah. Oleh karena itu, tujuan penelitian ini adalah mengetahui seberapa besar pengaruh fenomena tersebut terhadap wilayah Pulau Jawa. Data yang digunakan adalah reanalisis suhu permukaan laut dari AVHRRNOAA, Satelit Himawari-8 Kanal IR, data Radiosonde dan Sinoptik dari Stasiun Meteorologi Cilacap, data Streamline dari BoM, dan data curah hujan Satelit GSMAP selama periode Siklon Tropis Cempaka. Metode yang digunakan adalah teknik Dvorak, teknik HCAI, dan komposit pemetaan secara spasial dan temporal. Dapat diketahui bahwa suhu permukaan laut pada saat itu lebih $28,4{ }^{\circ} \mathrm{C}$ dengan anomalinya sebesar lebih dari $0,2{ }^{\circ} \mathrm{C}$. Intensitas Siklon Tropis yang terjadi mencapai T-Number 2,5, kecepatan maksimum di sekitar Siklon \pm 35 knot, dan pusat tekanan rendah mencapai $997 \mathrm{mb}$. Terdapat daerah konvektif kuat disekitar wilayah Siklon dan sangat mempengaruhi sistem cuaca yang terjadi. Sirkulasi udara tertarik ke arah pusat Siklon dan kondisi atmosfer cukup labil. Selain itu, kecepatan angin permukaan mengalami peningkatan hingga mencapai 14 knot sehingga mengakibatkan terjadinya fenomena banjir. Curah hujan yang terjadi di Selatan Pulau Jawa mencapai lebih dari 200 $\mathrm{mm} / \mathrm{hari}$.
\end{abstract}

Kata kunci :Awan, Satelit Himawari-8, Tunggulwulung, Siklon Tropis, Cempaka

\begin{abstract}
On November 27, 2017 at 19.00 pm was formed Tropical Cyclone Cempaka in Southern Coast of Java Island. The phenomenon is caused by anomalies and significant sea surface temperature in the region, triggering large energy transfers in ocean and atmospheric interactions. The exstence of tropical cyclone that cause changes weather either directly or indirectly in Indonesia is no exception in Southern Coast of Java Island. Therefore, the purpose of this study is to find out how the influence of the phenomenon to the region of Java. The data used are sea surface temperature analysis of AVHRR-NOAA, Satellite Himawari-8 IR, Radiosonde and Synoptic data from Cilacap Meteorological Station, Streamline from BoM. The methods used are Dvorak and HCAI techniques, statistics, analysis spatial and temporal It can be seen that the sea surface temperature was more $28.4 \mathrm{oC}$ with anomaly of more than 0.2 oC. Intensity that occurs reaches T-Number 2.5, the maximum speed near Cyclone \pm 35 knots, and the low pressure center reaches $997 \mathrm{mb}$. Top Dense Cloud reach more $16 \mathrm{~km}$ from $\mathrm{msl}$ and following thick cloud to Java Island. Air circulation is attracted towards the center of Cyclone and the atmosphere is quite unstable.
\end{abstract}

Keywords :factual, purpose, principal results, no references, conclusions 


\section{Pendahuluan}

Siklon tropis adalah sistem angin pusaran yang biasanya terbentuk di lautan dimana suhu permukaan lautnya melebihi $26,5^{\circ} \mathrm{C}$ (daerah pusat tekanan rendah di tropis) diantara garis lintang $\pm 5^{\circ}$ Lintang Utara Selatan (LU/LS) menjauhi ekuator [12]. Pada tanggal 27 November 2017 pukul 20.00 WITA di Perairan sebelah Selatan Jawa Tengah (100 km sebelah selatan - tenggara Cilacap) sekitar 8,60 LS dan 110,80 BT. Siklon Tropis Cempaka memberikan dampak terjadinya hujan dengan intenistas sedang hingga lebat yang disertai kilat/petir di wilayah DKI Jakarta, Banten, Jawa Barat, Jawa Tengah, DI Yogyakarta, Jawa Timur dan Bali, angin kencang di Selatan Jawa, serta gelombang tinggi di Perairan Selatan Pulau Jawa, Bali, hingga NTB [13].

Menurut Tjasyono [11], Siklon Tropis mula-mula muncul sebagai gangguan tropis, tetapi jika kecepatan angin meningkat menjadi sekitar 20 knot, dan terdapat satu isobar tertututp atau lebih, maka gangguan menjadi depresi tropis. Kecepatan angin mengingkat antara 34 knot dan 64 knot, dan terdapat beberapa isobar tertutup di sekitar mata, maka depresi menjadi badai tropis. Kecepatan angin melebihi 64 knot, maka badai meningkat menjadi siklon tropis.

Mekanisme dan Syarat-syarat pembentukan Siklon Tropis. Terdapat enam kondisi penting untuk dapat berkembangnya Siklon Tropis [3], yaitu terdapat air laut yang hangat dengan temperatur sekitar 26,5 $\mathrm{C}$ hingga kedalaman tertentu (sekitar 50 meter). Air hangat inilah yang berperan sebagai "bahan bakar" bagi mesin pembangkit energi panas siklon tropis. Atmosfer yang mengalami pendinginan secara cepat terhadap ketinggian. Adanya lapisan yang relatif basah dekat troposfer bagian tengah (pada ketinggian $5 \mathrm{~km}$ ). Jarak minimum terhadap ekuator setidaknya $500 \mathrm{~km}$. Hal ini karena dalam pembentukan siklon, diperlukan gaya semu Coriolis untuk mengimbangi gradien tekanan. Tanpa adanya gaya Coriolis, daerah tekanan rendah tidak akan dapat terus dipertahankan. Adanya gangguan dekat permukaan dengan vortisitas dan konvergensi yang mencukupi. Siklon tropis tidak dapat terjadi dengan tiba-tiba, ia memerlukan suatu sistem dengan putaran dan aliran di dekat permukaan yang cukup besar. Shear angin vertikal yang rendah di antara permukaan dan bagian atas troposfer (kurang dari 10 $\mathrm{m} /$ detik).

\section{Data dan Metode Penelitian}

\subsection{Anomali Dan SuhuPermukaanLaut}

Data SPL yang digunakan berasal dari data reanalisis resolusi tinggi AVHRRNOAA yang dapat diunduh melalui www.esrl.noaa.gov. Data tersebut memiliki resolusi sebesar $0,25^{\circ} \times 0,25^{\circ}$ dengan format nc secara rata-rata harian selama kejadian Siklon Tropis Cempaka, yaitu tanggal 27-29 November 2017.

Analisis SPL perlu dilakukan karena merupakan salah satu penyebab terjadinya fenomena tersebut. Siklon Tropis dapat terjadi ketika SPL hangat lebih dari 26,5 ${ }^{\circ} \mathrm{C}$ dengan anomali yang besar. 


\subsection{Data SatelitHimawari 8-Kanal IR}

Data Satelit yang digunakan berasal dari data Satelit Himawari-8 Kanal IR yang diperoleh dari Badan Meteorologi Klimatologi Geofisika (BMKG).Data tersebut mempunyai ripitasi tiap 10 menit selama periode Siklon Tropis Cempaka, yaitu 27-29 November 2017.

Analisis data satelit menggunakan teknik Dvorak untuk mengetahui kondisi siklus hidup Siklon Tropis Cempaka. Sehingga dapat diketahui fase waktu ternjadinya Siklon, baik Fase Pertumbuhan, Fase Dewasa, dan Fase Peluruhan. Kemudian dapat digunakan untuk menentukan intensitas Siklon berupa T-Number, Skala Saffir-Simpson, kecepatan maksimum, dan tekanan udara di sekitar pusat badai. Selain itu, melalui metode High-resolution Cloud Analysis Information dapat diamati estimasi jenis dan ketinggihan awan di sekitar badai.

\subsection{Data Pengamatan Udara Atas (Radiosonde)}

Data Radiosonde dan Sinoptik yang digunakan berasal dari Stasiun Meteorologi Cilacap (WMO 96805) pada jam 00.00 UTC untuk tanggal 27-29 November 2017. Data Radiosonde dapat diunduh melalui www.weather.uwyo.edu dalam format .txt.

Analisis data Radiosonde perlu dilakukan karena untuk mengetahui labilitas udara atas saat terjadinya badai. Digunakan data dari Stasiun Meteorologi Cilacap karena merupakan Stasiun pengamatan udara atas terdekat dari pusat Siklon sehingga diharapkan mampu mempresentasikan tingkat kestabilan udara atas yang dinyatakan dengan indek KI(K-Index), LI(Lifted Index), TT(Total Totals Index), SWEAT(Severe Weather Threat), dan CAPE(Convective Available Potential Energy).

\subsection{Data Streamline}

Data Streamline yang digunakan berasal dari Bureau of Meteorology (BoM) Australia yang dapat diunduh melalui www.bom.gov.au. Data tersebut diambil saat periode fase matang Siklon Tropis Cempaka, yaitu tanggal 28 November 2018 jam 00.00 UTC untuk Wilayah Indonesia Bagian Barat.

Analisis data Streamline perlu dilakukan karena untuk mengetahui aliran sirkulasi udara saat kejadian badai tersebut. Selain itu dapat digunakan untuk mengetahui wilayah yang berpotensi mengalami perubahan cuaca secara signifikan.

\subsection{Data Distribusi Curah HujanGlobal Satellite Mapping of Precipitation (GSMaP)}

Data distribusi curah hujan diperoleh dari Satelit Pengamatan GSMaP yang dapat diunduh melaluihttp://sharaku.eorc.jaxa.jp. Data tersebut digunakan untuk mengetahui distribusi curah hujan di wilayah penelitian selama periode Siklon Tropis Cempaka, yaitu 27-19 November 2017.

Titik yang bertanda Hijau merupakan lokasi Bandara Tunggulwulung Cilacap. Sedangkan titik yang bertanda merah merupakan titik terjadinya Siklon Tropis 
Cempaka pada tanggal 27-28 Februari 2017. Jarak antara Bandara Tunggulwulung dengan kejadian Siklon Tropis Cempaka adalah sekitar $230 \mathrm{~km}$.

\subsection{Letak Kejadian}

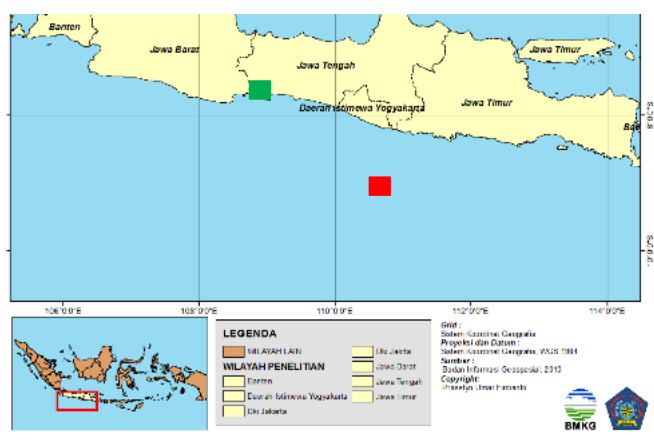

Informasi Umum Bandara Tunggulwulung :

1. IATA : CXP

2. ICAO : WIHL

3. Koordinat : $007^{\circ} 38^{\prime} 39^{\prime \prime} \mathrm{S} 109^{\circ} 02^{\prime} 04^{\prime \prime} \mathrm{E}$

4. Elevasi : 64,32 feet

Gambar 1. Wilayah Penelitian di Bandar Udara Tunggulwulung, Cilacap Jawa Tengah

\section{Hasil dan Pembahasan}

\subsection{Analisis Suhu Permukaan Laut (SPL)}

(a)

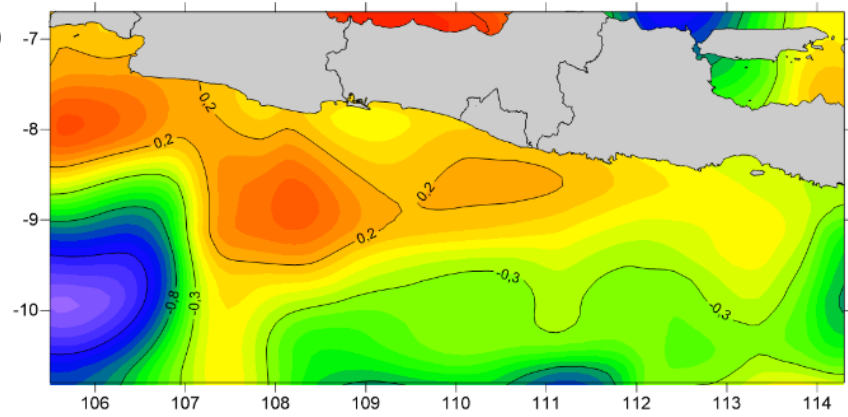

(b)

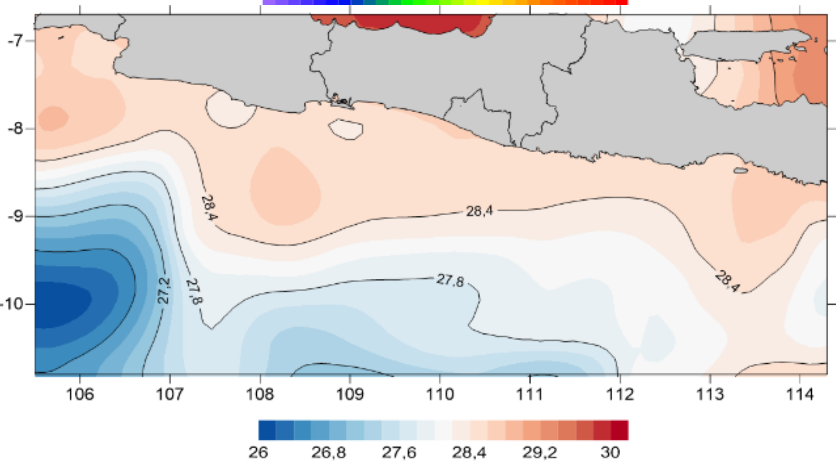

Gambar 2.Tanggal 27-29 November 2017

(a) AnomaliSuhuPermuakaanLaut Rata-rata Harian, (b) SuhuPermukaanLaut Rata-rata Harian

Gambar diatas menunjukan anomali dan suhu permukaan air laut selama periode Siklon. Dari Gambar 2a dapat diketahui bahwa terjadi anomali SPL yang cukup besar di Perairan Selatan Jawa, yaitu mencapai lebih dari $+0,2{ }^{\circ} \mathrm{C}$. Hal tersebut menimbulkan kondisi laut menjadi hangat, yang dipresentasikan oleh Gambar $2 \mathrm{~b}$. 
Terlihat bahwa SPL mencapai lebih dari $28,4{ }^{\circ} \mathrm{C}$. Kondisi inilah yang memicu terjadinya Siklon Tropis Cempaka karena saat SPL menghangat, maka terjadi pembangkitan energi yang kuat dalam interaksi laut dan atmosfer. Teramati bahwa SPL paling besar anomalinya berada di bagian Selatan Provinsi Jawa Tengah dan merupakan tempat bangkitnya Siklon Tropis Cempaka.

\subsection{Analisis Meteorologi Udara Atas}

Tabel 1Indek Hasil Pengamatan Radiosonde StasiunMeteorologiCilacap

\begin{tabular}{cccccc}
\hline Tanggal & KI & LI & TT & SWEAT & CAPE \\
\hline 27 & 36,9 & $-1,4$ & 42,1 & 264,0 & 343 \\
28 & 38,3 & $-2,4$ & 44,1 & 252,4 & 574 \\
29 & 36,3 & $-1,1$ & 43,1 & 257,4 & 220 \\
\hline
\end{tabular}

Berdasarkan analisis kondisi udara atas pada pukul 00.00 UTC pada saat kejadian Siklon Tropis Cempaka (27, 18, 29 November 2017), indeks labilitas menunjukkan adanya perbedaan nilai indeks. Pada indeks KI yang menunjukkan peluang terbentuknya massa udara pembentuk thunderstorm.mengalami nilai indeks tertinggi pada hari ke-2 kejadian Siklon Tropis yaitu sebesar 38,3 dari nilai KI pada hari pertama dan ke-tiga, sehingga pada hari tersebut potensi terbentuknya thunderstorm adalah yang terbesar. Begitu juga pada indeks TT yang mengindikasikan potensi kelabilan atmosfer melalui proses konveksi yang terjadi. Peningkatan kelabilan atmosfer juga ditunjukkan pada nilai indeks TT hari ke-dua Siklon Ttropis Cempaka, yaitu 44,1. Pada indeks LI, nilai indeks menunjukkan angka terendah pada hari ke-dua kejadian Siklon Tropis Cempaka yang menunjukkan kondisi atmosfer paling labil selama tiga hari kejadian siklon tropis tersebut.

Indeks SWEAT pada hari pertama Siklon Tropis Cempaka memiliki nilai terbesar yang mengindikasikan bahwa potensi cuaca terburuk lebih tinggi disbanding hari ke-dua dan ke-tiga. CAPE menunjukkan potensi energi yang mendukung tingkat konvektivitas. Pada hari ke-dua Siklon Tropis Cempaka, nilai CAPE berada pada nilai terbesar yaitu $574 \mathrm{~J} / \mathrm{Kg}$ yang mengindikasikan potensi energi dalam proses konvektif yang lebih besar dari nilai indeks pada hari pertama dan ke-tiga, namun berdasarkan intensitasnya menunjukkan konveksi lemah/cumulus.

\subsection{Analisis Streamline}

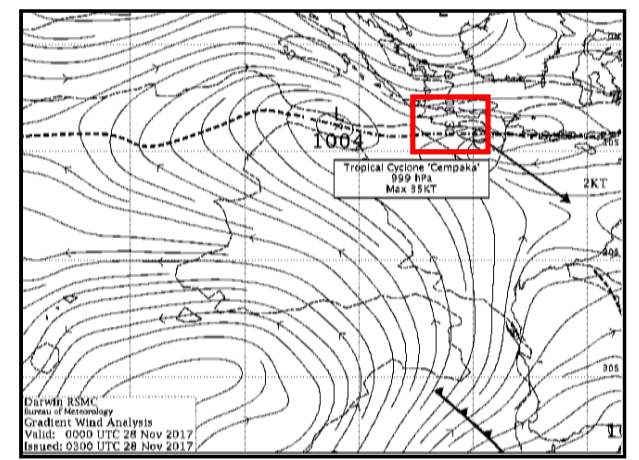

Gambar 3.Streamline Perairan Selatan Jawa saat Fase Matang Siklon Tropis Cempaka 
Dari Gambar 3 diatas dapat diketahui bahwa saat kejadian Siklon Tropis Cempaka, terdapat tarikan aliran udara ke pusat badai tekanan rendah yang mencapai 999 hPa saat tanggal 28 November 2017 jam 00.00 UTC. Tarikan udara tersebut terjadi secara konvergen. Hal tersebut yang menyebabkan terjadinya penumpukan awan di pusat badai sehingga menimbulkan pertumbuhan awan yang kuat secara konvektif. Di wilayah Cilacap, teramati bahwa massa udara tertarik menuju pusat Siklon

\subsection{Analisis Pertumbuhan Siklon Tropis Cempaka dengan Teknik Dvorak}

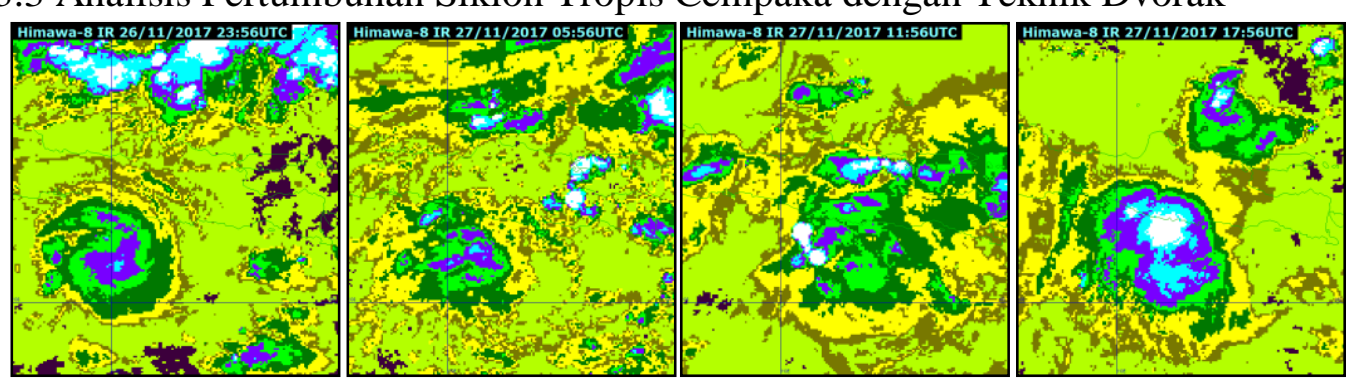

(a)

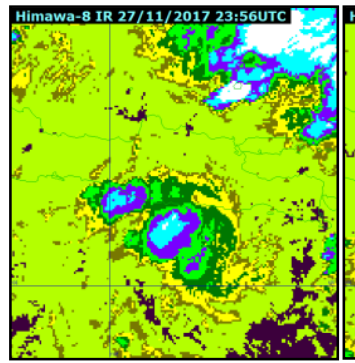

(e)

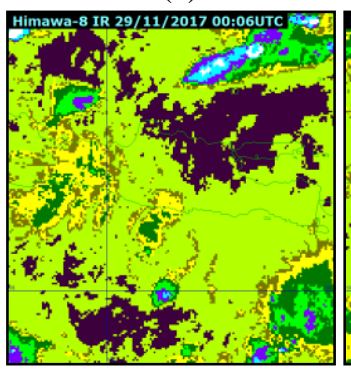

(i) (b)

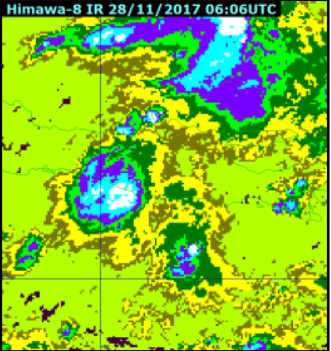

(f)

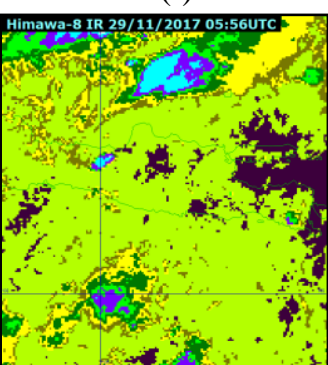

(j) (c)

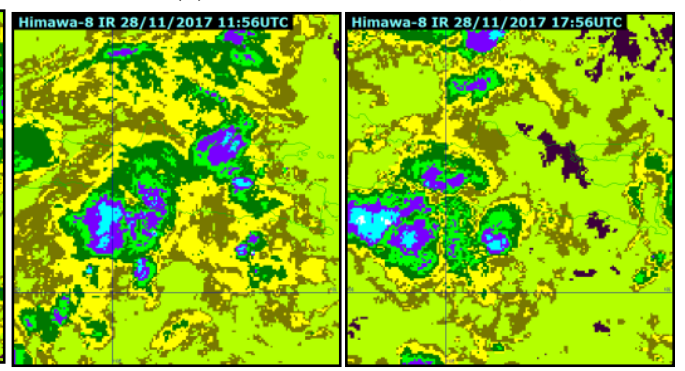

(g)

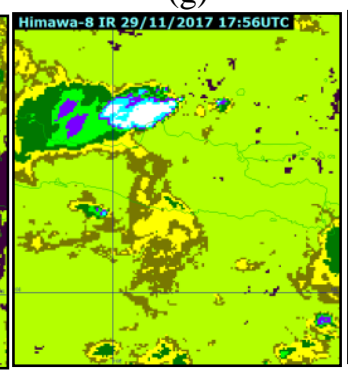

(k) (d)

Gambar 4.Citra Satelit Himawari-8 IR saat kejadian Siklon Tropis Cempaka dengan menggunakan SATAID pada Bulan November 2017. (a) dan (b) saat tanggal 27. (c) dan (d) saat tanggal 28. (e) dan (f) saat tanggal 29.

Dari Citra Satelit kanal IR, dapat diketahui bahwa pada tanggal 26 November 2017 jam 23.56 UTC sudah terlihat adanya TD (Tropical Depression). Fase matang dengan kategori TS (Tropical Storm), teramati mulai terjadi pada tanggal 27 November 2017 jam 17.56 UTC (Gambar 4b) dan berlanjut sampai tanggal 28 November 2017. Kemudian, memasuki fase punah setelahnya yang dapat dipresentasikan oleh Gmabar 4g, 4h, 4i, 4j, 4k, dan 4l. Selain itu, dari Gambar 4 dapat dilihat pergerakan Siklon Tropis Cempaka cenderung ke arah Barat Daya. 
Tabel 2. Pengolahan Data Satelit Himawari-8 Kanal IR saat kejadian Siklon Tropis Cempaka dengan Metode Dvorak

\begin{tabular}{llllll}
\hline \multirow{2}{*}{ Tgl } & $\begin{array}{l}\text { Jam } \\
\text { (UTC) }\end{array}$ & $\begin{array}{l}\text { T- } \\
\text { Number }\end{array}$ & $\begin{array}{l}\text { Skala } \\
\text { Saffir- } \\
\text { Simpson }\end{array}$ & $\begin{array}{l}\text { Kec. } \\
\text { Mak } \\
(\mathrm{knot})\end{array}$ & $\begin{array}{l}\text { Tekanan } \\
\text { Udara } \\
(\mathrm{mb})\end{array}$ \\
\hline \multirow{4}{*}{27} & $00: 00$ & 1.5 & TD & 25 & - \\
& $06: 00$ & 1.5 & TD & 25 & - \\
& $12: 00$ & 2.0 & TD & 30 & 1000 \\
& $18: 00$ & 2.5 & TS & 35 & 997 \\
\hline \multirow{4}{*}{28} & $00: 00$ & 2.5 & TS & 35 & 997 \\
& $06: 00$ & 2.5 & TS & 35 & 997 \\
& $12: 00$ & 2.5 & TS & 35 & 997 \\
& $18: 00$ & 2.0 & TD & 30 & 1000 \\
\hline \multirow{2}{*}{29} & $00: 00$ & 1.5 & TD & 25 & - \\
& $06: 00$ & 1.0 & TD & 25 & - \\
& $12: 00$ & 1.0 & TD & 25 & - \\
\hline
\end{tabular}

Metode Dvorak merupakan salahs satu cara yang efektif dalam menganalisis Siklon Tropis. Dari analisis Metode Dvorak, dapat dipresentasikan seperti pada Tabel 1. Dapat diketahui bahwa masa TD dari jam 00-12 UTC tanggal 27 November 2017 mempunyai kecepatan maksimum sebesar 25-30 knot (T-Number 1,5-2,0). Saat fase matang masa TS mempunyai kecepatan maksimum 35 knot dengan tekanan 997 milibar (T-Number 2,5), terjadi mulai jam 18.00 UTC tanggal 27 November 2018 hingga jam 12.00 UTC tanggal 28 November 2018. Kemudian mulai meluruh mulai jam 18.00 UTC tanggal 28 November 2017 dengan membentuk TD (T-Number 2,0-1,0).

\subsection{Analiss Mikrofasis Awan}
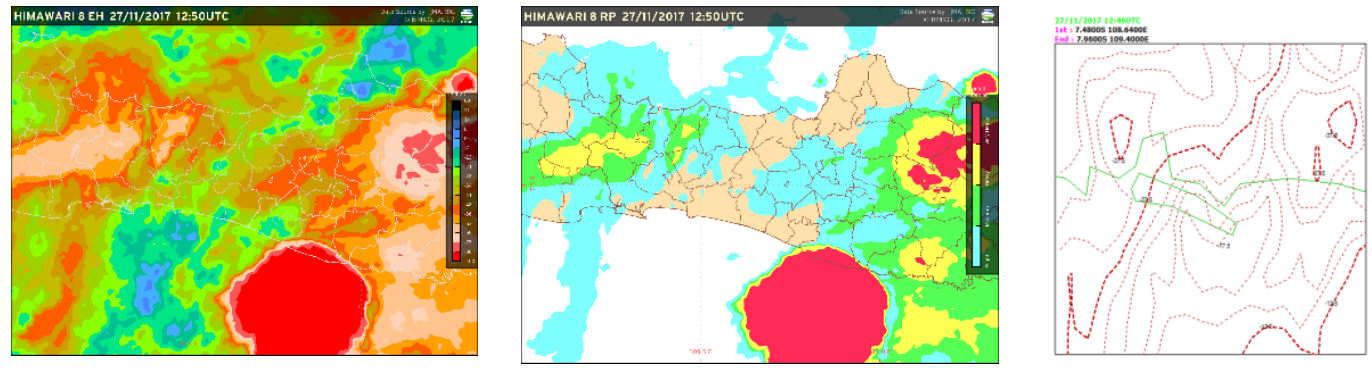

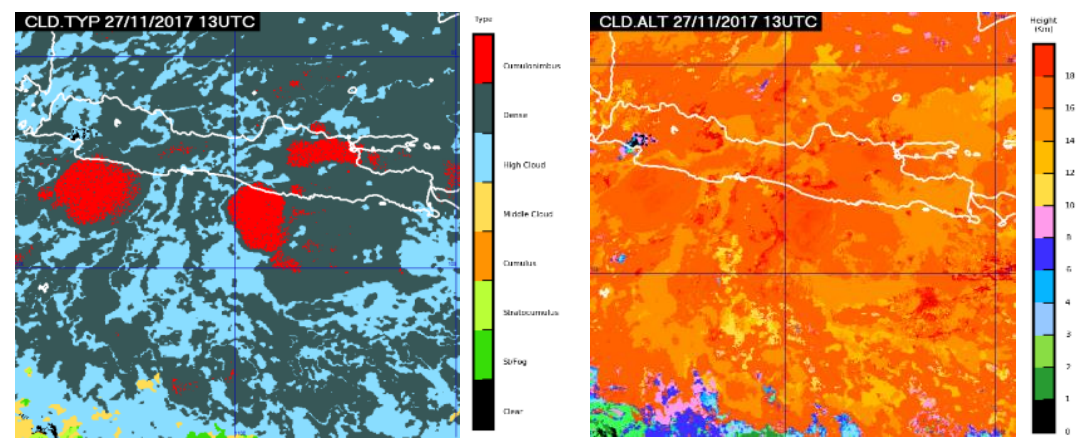

Gambar 5. Kondisi Awan Fase Pertumbuhan. (a) Suhu Puncak Awan, (b) Rainfall Potential, (c) Kontur Isoline Suhu Puncak Awan
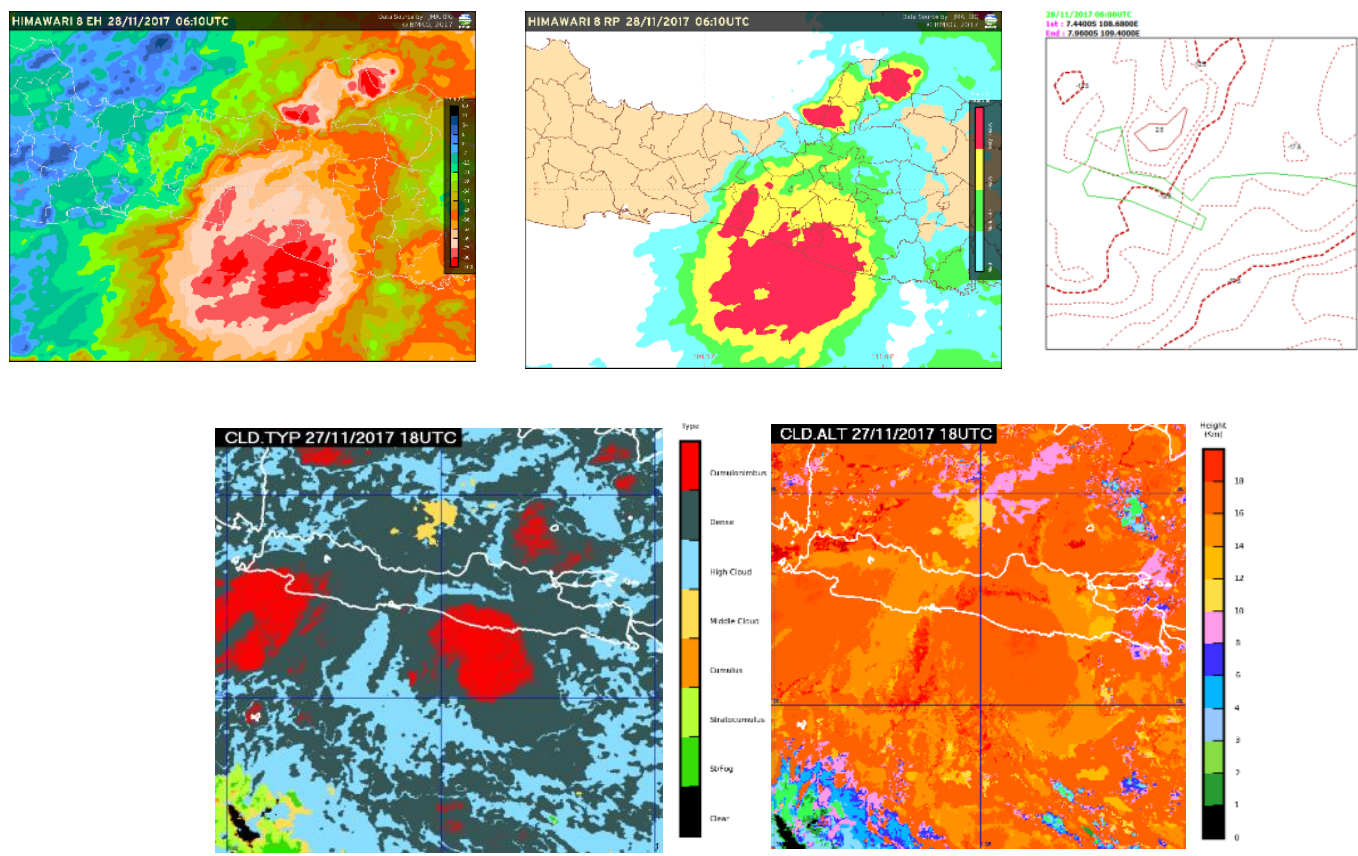

Gambar 6.Kondisi Awan Fase Pertumbuhan. (a) Suhu Puncak Awan, (b) Rainfall Potential,(c) Kontur Isoline Suhu Puncak Awan
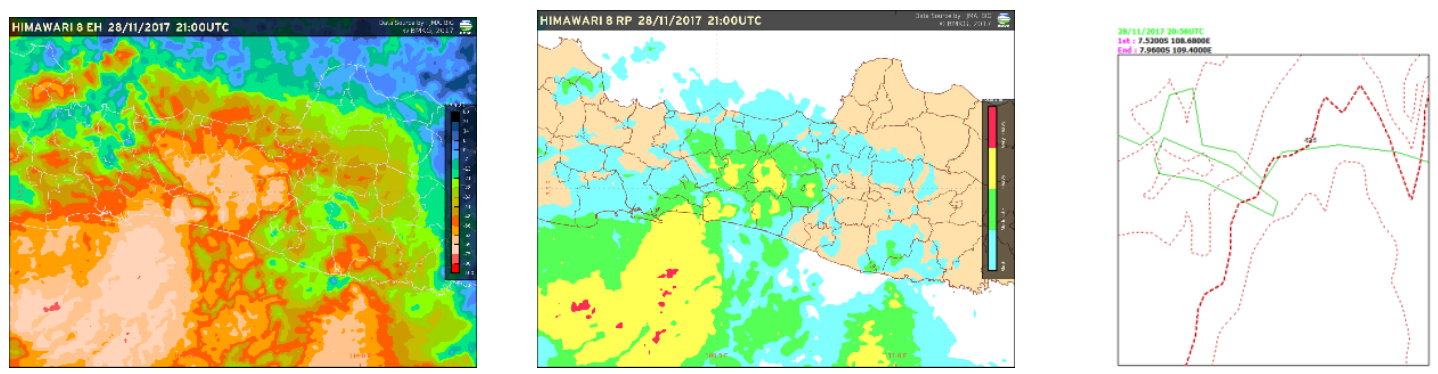


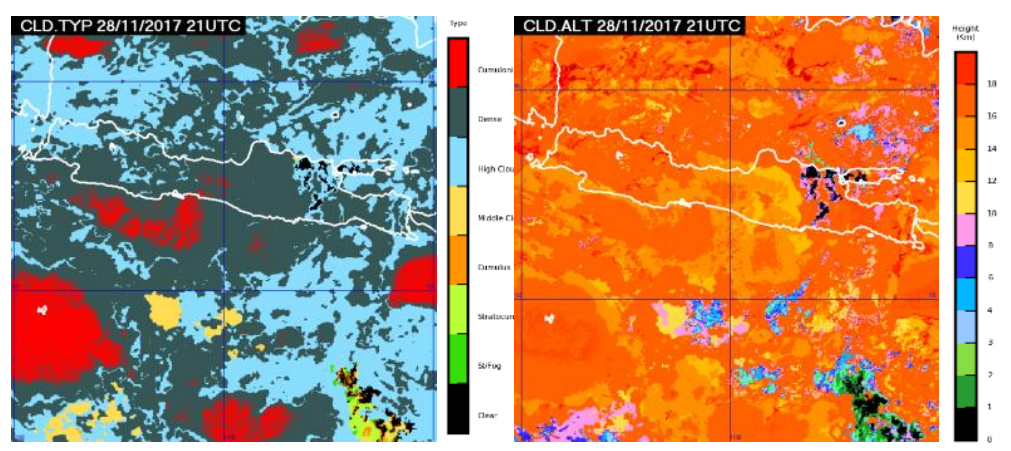

Gambar 7.Kondisi Awan Fase Peluruhan. (a) Suhu Puncak Awan, (b) Rainfall Potential, (c) Kontur Isoline Suhu Puncak Awan

\subsection{Estimasi Distribusi Curah Hujan GSMaP}
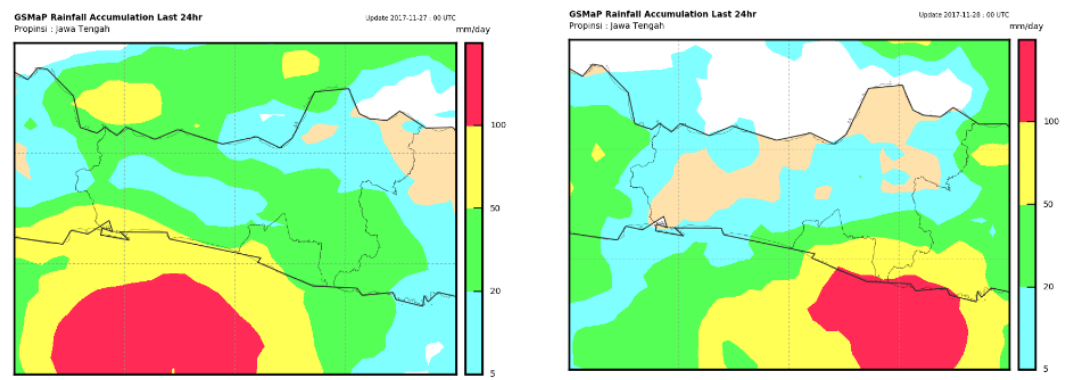

Gambar 8.Curah Hujan GSMAP Bulan November 2017 di Wilayah Cilacap. (a) Tanggal 27.

(b) Tanggal 28

Dapat diketahui dari Gambar diatas bahwa Curah hujan yang terjadi mencapai lebih dari $50 \mathrm{~mm} /$ hari. Sehingga dapat dikategorikan hujan yang lebat. Akibatnya, di wilayah Cilacap terjadi banjir yang cukup parah.

\section{Kesimpulan}

Dari uraian analisis hasil dan pembasan dapat diketahui bahwa SiklonTropis Cempaka mempunyai intensitas yang cukup besar. Hal ini dapat dilihat dari analisis citra satelit dengan menggunakan Metode Dvorak. Intensitas Siklon yang terjadi mencapai T-Number 2,5 dengan kecepatan maksimum di sekitar Siklon mencapai 35 knot dengan pusat tekanan rendah mencapai $997 \mathrm{mb}$.

Terdapat daerah konvektif kuat disekitar wilayah Siklon dan sangat mempengaruhi system cuaca di sekitar Bandara Tunggul wulung Kabupaten Cilacap. Diantaranya adalah mengakibatkan kondisi udara menjadi labil, langit yang tertutup awan secara dominan, tertariknya massa udara kearah pusat badai, terjadi peningkatan kecepatan angin permukaan di Bandara Tunggul wulung curah hujan sehingga menyebabkan banyak daerah yang terkena bencana banjir, tanah longsor dan gelombang tinggi yang disebabkan oleh adanya fenomena Siklon Tropis Cempaka. 


\section{Ucapan terima kasih}

Ucapan terimakasih kami tunjukan kepada KetuaSekolah Tinggi Meteorologi Klimatologi Geofisika yang telah mendukung dalam penulisan ini. Kemudian dosen kami, Bapak Ahmad Fadlan yang sekaligus sebagai penulis kedua dalam tulisan ini, yang telah membimbing dan membantu dalam menyelesaikan tulisan ini.

\section{Daftar Pustaka}

1. Chang et al. 2005. Synoptic Disturbances Over the Equatorial South Cina Sea Western Continent During Boreal Winter. Mon. Wea. Rev. 133. 489-503.

2. D. L. William, 1975. Meteorology. Fourth edition. Mc. Graw-Hill.

3. W. M. Gray, Global view of the origins of tropical disturbance and storm.Mon. Wea. Rev. 96 (1975) p. 669-700.

4. M. Neiburger, 1995. Memahami Lingkungan Atmosfer Kita. Purbo Ardina, penerjemah. Terjemahan dari Understanding Our Atmosphere Environment. Bandung: Penerbit ITB.

5. H. Suharsono, 1993. Iklim Tropika dalam Klimatologi Dasar. (Ir.Handoko,ed). Fakultas Matematika dan IPA Institut Pertanian Bogor. (1993) p. 175-187.

6. T. June, 1993. Angin dalam Klimatologi Dasar. (Ir.Handoko,ed). Fakultas Matematika dan IPA Institut Pertanian Bogor (1993) p. 79-90.

7. Putri dkk., "Description of Atmospheric Parameters Due to Waterspout in Tarakan August 26th 2015 (North Kalimantan-Indonesia)". Prosiding of The 6th International Symposium for Sustainable Humanosphere (2017) p. 64-69.

8. Ruslana dan Sulistyowati, "Analisis Pengaruh Siklon Tropis Cempaka terhadap Kejadian Banjir dan Longsor di Kabupaten Wonogiri Propinsi Jawa Tengah (28 November 2017)". www.bmkg.go.id (Accessed on 10 Mei 2017)

9. TCWC Jakarta, Recent and Curret Activities of The TC RSMCs/TCWCs. Report On Current and Planned Activities RA V Tropical Cyclone Committee Sixteenth Session (2016).

10. B. Tjasyono, The Impact of Tropical Storms on the Weather Over Indonesia. Conference Proceedings. Weather Modification Technical Service Unit. Agency for Assesment and Aplication of Technology: Jakarta (1999)

11. B. Tjasyono, Pengantar Geosains. Bandung: Penerbit ITB (2000).

12. G. T. Trewartha, Pengantar Iklim Edisi Kelima.Gadjah Mada University (1995). 